\title{
Angiomodulatory properties of some antibiotics and Tołpa Peat Preparation
}

\author{
DOROTA M. RADOMSKA-LEŚNIEWSKA I', EWA SKOPIŃSKA-RÓŻEWSKA ${ }^{2,3}$, \\ JAROSŁAW JÓŹWIAK ${ }^{1}$, URSZULA DEMKOW', BARBARA JOANNA BAEAN
}

${ }^{1}$ Department of Histology and Embryology, Biostructure Centre, Medical University of Warsaw, Warsaw, Poland

${ }^{2}$ Department of Pathomorphology, Biostructure Centre, Medical University of Warsaw, Warsaw, Poland

${ }^{3}$ Military Institute of Hygiene and Epidemiology, Warsaw, Poland

${ }^{4}$ Department of Laboratory Diagnostics and Clinical Immunology of Developmental Age, Medical University of Warsaw, Warsaw, Poland ${ }^{5}$ Department of Immunology, Biochemistry, and Nutrition, Medical University of Warsaw, Warsaw, Poland

\begin{abstract}
Deterioration of the immune system due to antibiotic therapy can be restored by immunomodulator application. In this paper we estimate the effect of ampicillin, amikacin, doxycycline, rifampicin, rifamycine and immunomodulator Totpa Peat Preparation (TPP) on neovascular reaction induced in murine skin by human mononuclear cells (MNC) injection. MNC originating from 15 healthy volunteers were injected intradermally to Balb/c mice. Antibiotics (3, 15, or $75 \mathrm{mg} / \mathrm{kg}$ of body weight) alone or with TPP (10 mg/kg of body weight) were administrated subcutaneously to mice on three consecutive days. The number of newly formed blood vessels was measured in dissection microscope 72 hours after cell injection. Results: TPP stimulated angiogenic activity of MNC at the dose 5 and $10 \mathrm{mg} / \mathrm{kg}$. Rifamycine exerted strong stimulatory action, ampicillin slightly stimulated immune response, while doxycycline and rifampicin downregulated it. Amikacin did not influence the results of angiogenesis tests. Studied antibiotics $(15 \mathrm{mg} / \mathrm{kg})$, except rifamycine, inhibit the angiostimulatory effect of the tested immunomodulator. TPP should be applied after antibiotic therapy to maintain its stimulatory effect and restore proper host immune function.
\end{abstract}

Key words: antibiotics, angiogenesis, Totpa Peat Preparation (TPP), amikacin, ampicillin, doxycycline, rifamycine, rifampicin, immune system.

(Cent Eur J Immunol 2016; 41 (1): 19-24)

\section{Introduction}

Antibiotics are an essential part of modern medicine and are the only cure for numerous infectious diseases. However, this kind of therapy may produce side effects that can cause serious medical disorders. A negative impact on the immune system is one of them [1]. Correction of disturbed defensive system function may be assured by immune system modifiers, including immunomodulators. These substances are able to restore proper function of the immune system, i.e. increase the function that had been downregulated and suppress upregulated processes [2]. Tołpa Peat Preparation (TPP) belongs to this group of remedies.

Peat, a source of natural humic substances, has long been used in physiotherapy, rheumatology, and sports medicine. The study of biologically active substances isolated from peat was started in 1945 and was continued since 1956 by Wrocław Agricultural Academy, resulting in isolation of Tołpa Peat Preparation [3]. In 1988 the
Wrocław Agricultural Academy sold the licence for the production of the peat preparation on an industrial scale to the Polish-American company Torf Corporation based in Wrocław. TPP is known to have immunomodulatory and antioxidant properties, regulating a lot of processes, including immune response. Inglot et al. [4] described the stimulatory effect of TPP on cytokine production, such as tumour necrosis factor $\alpha$ and interferon $\alpha$ and $\gamma$ by human peripheral blood leukocytes. The same group published immunoprotective activity of peat preparation, performing studies of oral treatment of athletes with TPP [5]. Diminished angiogenic response of geriatric patients and patients with coronary heart disease was upregulated by TPP application in studies by Skopińska et al. [6]. The preparation restored abnormally high angiogenic activity of human leukocytes from rheumatoid arthritis (RA) patients, as well. Furthermore, spontaneous IL-1 production of monocytes from RA patients was inhibited by TPP. Krzemiński et al. [7] presented cardioprotective and im-

Correspondence: Barbara Joanna Bałan, Department of Immunology, Biochemistry, and Nutrition, Medical University of Warsaw,

Pawinskiego 3 A, 01-106 Warsaw, Poland, e-mail: vhm@post.pl

Submitted: 28.01.2016; Accepted: 3.02.2016 
munostimulatory effect of this remedy after experimental myocardial infarction in vivo (rat model).

Nowadays, TPP is offered in tablets containing $2.5 \mathrm{mg}$ of peat with specific indication for recurrent infections. The preparation is of potential interest to dermatologists and cosmetologists. Because of mild astringent and anti-inflammatory activity, humic substances are useful adjuncts in the topical therapy of inflammatory skin diseases, like atopic dermatitis, cheiropodopompholyx, psoriasis, and mild focal hyperhidrosis [8].

Angiogenesis, the process of new blood vessels formation from pre-existing ones, plays a key role in many physiological processes, including embryogenesis, reproductive function, or wound repair. As neovascularisation is a part of cell immunity, it can be a good model for the examination of immune response [9].

Knowledge concerning the antibiotic effects on the immune function is essential because antibiotic therapy is still prevalent. Therefore, the question of whether immunomodulators should be administered during or after antibiotic therapy is still valid. In this paper we evaluate the effect of five popular antibiotics and TPP (applied alone or together to mice) on the angiogenesis process in order to learn more about this issue.

\section{Material and methods}

The studies were conducted based on mononuclear cells (MNC) obtained from peripheral blood of 15 healthy volunteers from the Institute of Tuberculosis and Lung Diseases, Warsaw, Poland, all of whom signed Informed Consent forms.

The following antibiotics and immunomodulator were analysed:

- ampicillin (Polfa, Poland),

- amikacin sulphate (Amikacin, Polfa, Poland),

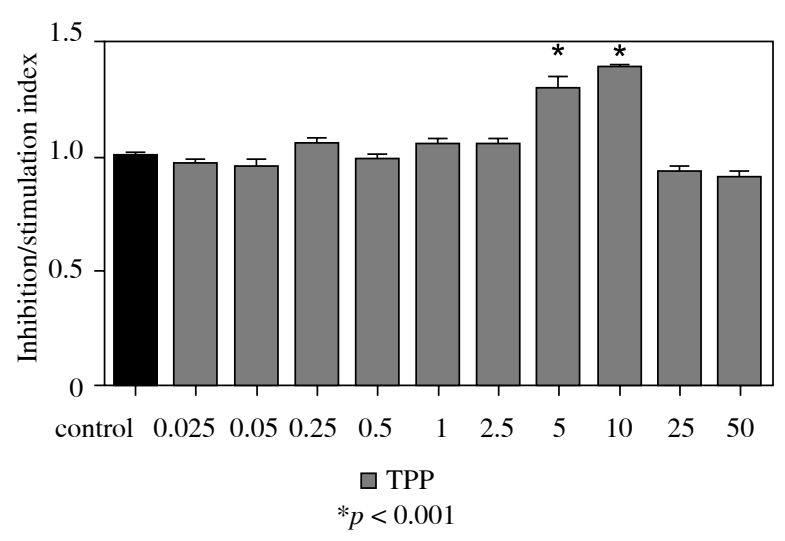

Fig. 1. The influence of various doses of Tołpa Peat Preparation (series: OHP G9R) on angiogenic activity of mononuclear cells
- doxycycline hydrochloride (Vibramycin, Polfa, Poland),

- rifampicin (Polfa, Poland),

- rifamycine (Rifamycin SV, Glaxo),

Tołpa Peat Preparation branch OHPG9R (Torf Corporation, Wrocław, Poland).

\section{Isolation of mononuclear leukocytes}

Isolation of mononuclear leukocytes (MNC) was performed according to Boyum method and was based on centrifugation of a blood sample on a gradient of Ficoll/ Uropoline [10]. The viability of isolated cells was estimated by trypan blue exclusion and was always higher than $98 \%$.

\section{Angiogenesis test}

Angiogenesis test was conducted according to Sidky and Auerbach [11] with Skopińska-Różewska et al. [12] modification. Experiments were performed on inbred Balb/c mice, 6-8 weeks old, from the Polish Academy of Sciences breeding colony. MNC $\left(5 \times 10^{5}\right.$ per inoculum $)$ resuspended in Parker medium were injected intradermally (4-6 injections per mouse) into flanks of pre-anaesthetised Balb/c mice. Antibiotics were administered subcutaneously to the mice in three daily doses: 3,15 , or $75 \mathrm{mg} / \mathrm{kg}$ of body weight (calculated from recommended human daily dose), for three consecutive days, beginning from the day of MNC injections. Tołpa Peat Preparation was administered subcutaneously at the following daily doses: $0.025,0.05,0.25,0.5,1,2.5,5$, 10,25 , and $50 \mathrm{mg} / \mathrm{kg}$ of mouse body weight. To examine the combined effect of antibiotic and TPP, the antibiotic was administered at the dose of $15 \mathrm{mg} / \mathrm{kg}$ and TPP $10 \mathrm{mg} / \mathrm{kg}$ to studied animals. The groups always consisted of three mice. Each experiment was repeated at least two times. After 72 hours the mice were sacrificed and newly formed blood vessels were counted using dissection microscope (magnification $6 x$ ) on the inner skin surface.

The experiments were approved by the Local Ethical Committee.

\section{Statistical analysis}

Angiogenic activity was calculated as a number of newly formed blood vessels and presented as quotient of: a) the newly formed blood vessels in tested group, and b) the mean number of newly formed blood vessels in control group, called the inhibition/stimulation index $(I=a / b)$. All data are shown as a mean \pm SEM. The differences between the groups were calculated by two-way ANOVA followed by Bonferroni post-test (GraphPadPrism software). The differences were considered significant at a $p$-value $<0.05$.

\section{Results}

The results are shown in Figs. 1-5.

Tołpa Peat Preparation exerted a dose-dependent effect in angiogenesis test (Fig. 1). 


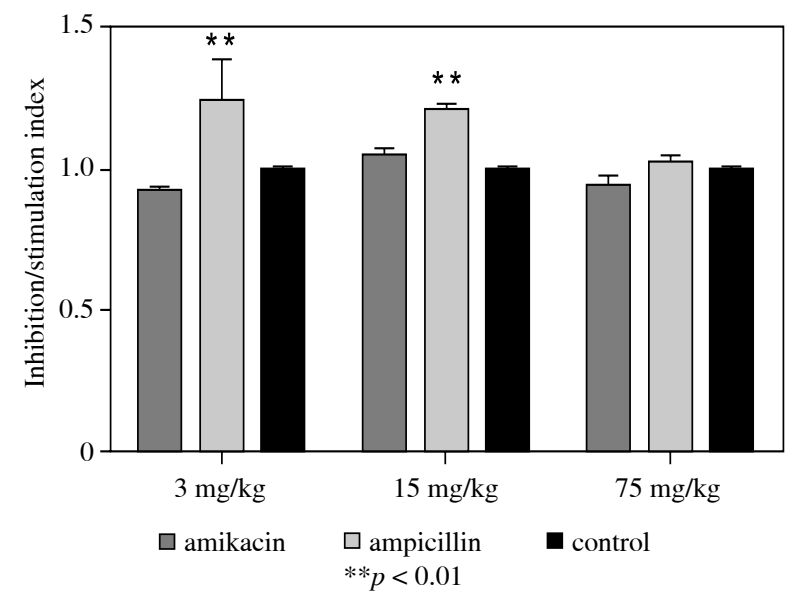

Fig. 2. The influence of various doses of ampicillin and amikacin on angiogenic activity of mononuclear cells

Among 10 TPP doses, ranges $0.025-50 \mathrm{mg} / \mathrm{kg}$ of body weight, only 5 and $10 \mathrm{mg} / \mathrm{kg}$ stimulated $(p<0.001)$ neovascular reaction. The most effective was $10 \mathrm{mg} / \mathrm{kg}$.

Ampicillin has shown angiostimulatory activity at lower doses ( 3 and $15 \mathrm{mg} / \mathrm{kg}$ ), although the effect was not strong $(p<0.01)$. The highest dose did not change MNC activity in angiogenesis test (Fig. 2).

Amikacin did not influence the angiogenic activity of the studied cells (Fig. 2).

Strong stimulation of angiogenesis was obtained for rifamycine administered to mouse at each studied dose. The highest effect was seen at $15 \mathrm{mg} / \mathrm{kg}$ (Fig. 3).

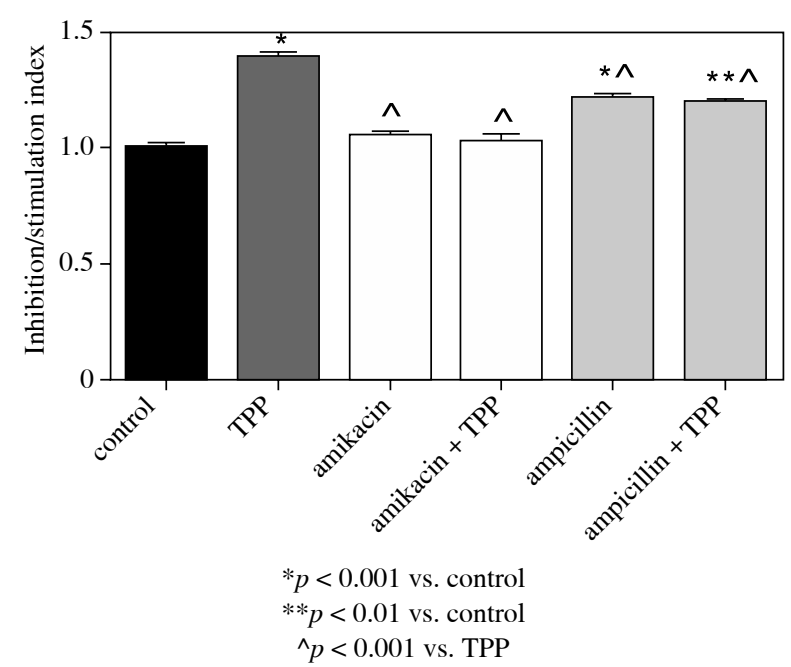

Fig. 4. Combined effect of antibiotic (ampicillin or amikacin) and Tołpa Peat Preparation (TPP) on angiogenic activity of mononuclear cells. Antibiotic and TPP were administered subcutaneously at the dose $15 \mathrm{mg} / \mathrm{kg}$ and $10 \mathrm{mg} / \mathrm{kg}$ of body mass, respectively

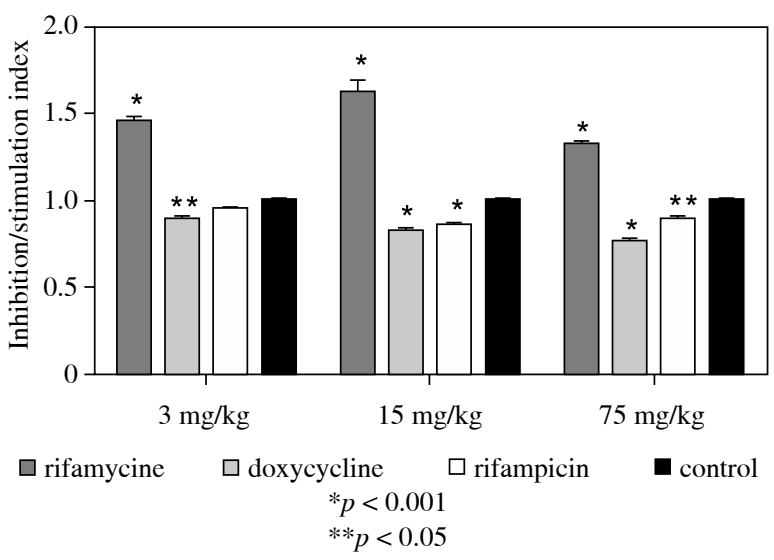

Fig. 3. The influence of various doses of doxycycline, rifamycine, and rifampicin on angiogenic activity of mononuclear cells

Rifampicin at the dose of $15 \mathrm{mg} / \mathrm{kg}(p<0.001)$ and $75 \mathrm{mg} / \mathrm{kg}(p<0.05)$ suppressed angiogenesis, while the smallest dose had no effect in neovascular reaction (Fig. 3).

Doxycycline diminished the results of angiogenesis test in each dose: $3 \mathrm{mg} / \mathrm{kg}(p<0.05), 15 \mathrm{mg} / \mathrm{kg}(p<0.001)$, and $75 \mathrm{mg} / \mathrm{kg}(p<0.001)$ (Fig. 3).

Almost all studied antibiotics ( $15 \mathrm{mg} / \mathrm{kg})$, except rifamycine, abolished the angiostimulatory effect of TPP $(10 \mathrm{mg} / \mathrm{kg})$ (Figs. 4 and 5). The results of angiogenesis tests in the groups receiving antibiotic (ampicillin, amikacin, rifampicin, doxycycline) and TPP were significantly $(p<0.001)$ decreased compared to the results from the

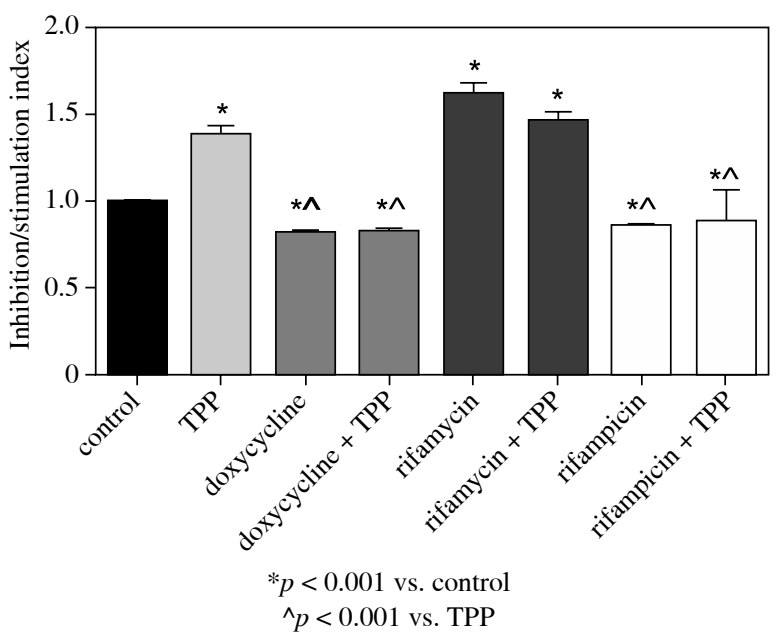

Fig. 5. Combined effect of antibiotic (doxycycline, rifamycine, or rifampicin) and Tołpa Peat Preparation (TPP) on angiogenic activity of mononuclear cells. Antibiotic and TPP were administered subcutaneously at the dose of $15 \mathrm{mg} / \mathrm{kg}$ and $10 \mathrm{mg} / \mathrm{kg}$ of body mass, respectively 
groups receiving TPP alone. There was no statistical difference between groups of mice receiving antibiotic alone (ampicillin, amikacin, rifampicin, doxycycline) and antibiotic with TPP. The results of angiogenesis tests in the groups injected rifamycine with TPP and rifamycine alone were at the same level (no statistical difference was seen).

\section{Discussion}

The knowledge of modulatory influence of antibiotics on immune function should be propagate and used in clinical practice. Occasionally, even suppression of some immune parameters can be of benefit in particular medical cases. An example is angiogenesis, a part of the cell immune response, which is abnormally increased in many diseases, including cancer, rheumatoid arthritis, and psoriasis. In those cases, during bacterial infection, application of antibiotic diminishing angiogenesis could have a double beneficial effect: antibacterial and restoring disturbed angiogenesis [1]. Antibiotic therapy in patients presenting normal immune function often causes a decrease of some immune function [13]. Our previous reports [9, 14] have shown that antibiotic effect on angiogenesis process depends on the type and dose of antibiotic. Cephalosporins, cephradine, cefsulodin, and ceftriaxone, in angiogenesis test, showed inhibitory activity, while cefuroxime and ceftazidime stimulated angiogenic response. Cefoperazone did not change the neovascular reaction induced by injection of healthy donors' MNC [14]. However, it stimulated angiogenic response of cells derived from bronchoalveolar lavage of sarcoidosis patients [15].

The modulatory effect of ampicillin on various parameters of immunity was reported several times [16-18]. It stimulated $\mathrm{GvH}$ reaction and antibody production in mice, while antibody-dependent cell-mediated cytotoxicity (ADCC) and PHA-induced reaction in mice was lowered by its administration $[16,17]$. Furthermore, ampicillin modulated human lymphocyte proliferation response to PHA - this effect depended on the dose [16]. The study of Wlodarska et al. [18] demonstrated that ampicillin administered to pregnant $\mathrm{C} 3 \mathrm{HW}$ mice modulates the immune reactivity of their offspring. The adult progeny of these mice presented lowered cellular immunity and a reduced percentage of $\mathrm{T}$ lymphocytes in the lymph nodes, while humoral immunity was enhanced.

The present study shows an increase in human MNC-induced angiogenesis at two studied doses (3 and $15 \mathrm{mg} / \mathrm{kg}$ ) of ampicillin, meaning that this antibiotic is safe for patients with proper or diminished immune function and can be safely used in bacterial infection.

Artsimowich et al. [19] demonstrated that amikacin did not influence humoral and cellular response $(\mathrm{GvH})$ of healthy mice and stimulated these parameters in cyclophosphamide-immunosuppressed animals. In vitro study showed [20] that humoral response of human lymphocytes was not modified by amikacin. Our investigation confirms these results. The angiogenic response of human MNC was not altered by amikacin in the present study. However, Roszkowski et al. [21] reported that seven-day amikacin Balb/c mice treatment by 3,15 , and $75 \mathrm{mg} / \mathrm{kg}$ of this drug lowered humoral response and LPS-induced lymphocyte activity.

Most investigators have reported inhibitory effects of doxycycline on various immune functions, such as chemotaxis, phagocytosis, intracellular bacteria killing, antibody production, and synthesis of proteins [13]. Delayed hypersensitivity reaction, mitogen-induced blast transformation of lymphocytes, in in vitro and in vivo studies was also reduced by doxycycline administration [13, 22]. The results of the angiogenesis tests presented in this paper showed an inhibitory effect of doxycycline administered to mice at each studied dose.

Rifamycines are a group of antibiotics that are synthesised either naturally by the bacterium Amycolatopsis rifamycinica, or chemically. Rifamycines are particularly effective against mycobacteria, and are therefore used to treat tuberculosis, leprosy, and Mycobacterium avium complex (MAC) infections. Rifamycine has been shown to increase many parameters of immune function, e.g. phagocytosis of mouse peritoneal macrophages after one week of administration (at doses 10-30 mg/kg) [23]. Amagay et al. [24] showed that rifamycine did not alter antibody production and Th lymphocyte activity and enhanced suppressor T lymphocyte activity. Ten-day therapy with this antibiotic did not influence delayed hypersensitivity reaction in mice [1].

The results of our work show a strong increase in angiogenic activity of human MNC at each dose of rifamycine. These results indicate the possibility to safely use this drug in the therapy of patients with suppressed immune function. Although rifampicin belongs also to rifamycines, it exerts contrary effects, diminishing angiogenic response at the dose of 15 and $75 \mathrm{mg} / \mathrm{kg}$. The smallest dose had no influence. Our previous results demonstrated that rifampicin administered at the dose of $50 \mathrm{mg} / \mathrm{kg}$ also inhibited angiogenesis [25]. Moreover, this study showed that rifampicin slightly stimulated the production of anti-SRBC antibodies and suppressed the cellular response in vivo in B6AF1 mice. It decreased PHA- and Con A-induced proliferation of lymphocytes (dose $70 \mu \mathrm{g} / \mathrm{ml}$ ) in in vitro studies. According to other investigations [26], long-term rifampicin treatment inhibits production of anti-SRBC antibodies $(20 \mathrm{mg} / \mathrm{kg})$ or exerts no influence [27]. Inhibition of mitogen-stimulated proliferation of lymphocytes and blast transformation was also shown in in vitro and in vivo study. It suppressed chemotactic activity of neutrophils. Long rifampicin treatment of tuberculosis patients diminished cellular response parameters, which returned to normal levels afterwards [27]. 
Tołpa Peat Preparation stimulated angiogenic activity of human MNC in average doses ( 5 and $10 \mathrm{mg} / \mathrm{kg}$ of body mass), exerting no influence on angiogenesis at lower and higher doses. Studied antibiotics $(15 \mathrm{mg} / \mathrm{kg})$, except rifamycine, abolished the angiostimulatory effect of $10 \mathrm{mg} / \mathrm{kg}$ TPP. A similar effect was obtained for erythromycin and cephradine in our previous investigations [28]. This fact implicates that TPP should be administered after therapy with these antibiotics. In contrast, rifamycine used with TPP did not alter the angiogenic activity of MNC. Clindamycin was demonstrated to have similar activity [28].

To sum up, our studies show a modulatory effect of antibiotic administration on immune function measured by angiogenesis test. Rifamycine exerted strong stimulatory action, ampicillin slightly stimulated immune response, while doxycycline and rifampicin downregulated it. Amikacin did not influence the results of the LIA test. The studied antibiotics ( $15 \mathrm{mg} / \mathrm{kg}$ ), except for rifamycine, abolished the angiostimulatory effect of TPP.

\section{Conclusions}

Antibiotics modulate angiogenesis and immune response.

Tołpa Peat Preparation should be applied after antibiotic therapy, in order to maintain its stimulatory effect and restore proper immune function.

The authors declare no conflict of interest.

\section{References}

1. Radomska D (1994): Antybiotyki a układ odpornościowy. Reumatologia 32: 63-68.

2. Radomska-Leśniewska DM, Skopiński P, Bałan BJ, et al. (2015): Angiomodulatory properties of Rhodiola spp. and other natural antioxidants. Cent Eur J Immunol 40: 249-262.

3. Tołpa S (1992): The history of the discovery and development of investigation on Tołpa Torf preparation. In: Preclinical investigation of Tołpa Torf Preparation (TPP). Danysz A (ed.) Torf Corporation, Wrocław.

4. Inglot A, Zielińska-Jenczylik J, Sypuła J (1993): A method to asses the immunomodulating effects of the Tolpa Torf Preparation (TTP) by measuring the hyporeactivity to interferon induction and tumor necrosis factor response. Arch Immunol Ther Exp 41: 87-93.

5. Inglot AD, Sobiech KA, Zielinska-Jenczylik J, et al. (1999): Development and disappearance of tolerance to induction of interferon and tumor necrosis factor response in athletes treated with natural immunostimulant. Arch Immunol Ther Exp (Warsz) 47: 237-244.

6. Skopińska-Różewska E, Polakowski I, Żukowska M, et al. (1993): The effect of Tołpa Peat Preparation (TPP) on human mononuclear leucocytes induced angiogenesis. Herba Polonica 39: 41-51.

7. Krzemiński TF, Nożyński JK, Grzyb J, et al. (2005): Angiogenesis and cardioprotection after TNF $\alpha$-inducer-Tołpa Peat
Preparation treatment in rat's hearts after experimental myocardial infarction in vivo. Vascul Pharmacol 43: 164-170.

8. Wollina U (2009): Peat: A natural source for dermatocosmetics and dermatotherapeutics. J Cutan Aesthet Surg 2: 17-20.

9. Radomska-Leśniewska DM, Skopińska-Różewska E, Malejczyk J (2010): The effect of clindamycin and lincomycin on angiogenic activity of human blood mononuclear cells. Centr Eur J Immunol 35: 217-222.

10. Boyum A (1968): Isolation of mononuclear cells by one centrifugation and sedimentation at $1 \mathrm{~g}$. Scand J Clin Lab Invest 97: 77-89.

11. Sidky YA, Auerbach R (1975): Lymphocyte-induced angiogenesis: a quantitative and sensitive assay for the graft versus-host reaction. J Exp Med 141: 1084-1100.

12. Skopińska-Różewska E, Sommer E, Demkow U, et al. (1997): Screening of angiogenesis inhibitors by modified TIA test in lung cancer. Annales Acad Med Bialostocensis 42 (Suppl 1): 287-296.

13. Pomorska-Mól M, Pejsa Z (2012): Effects of antibiotics on acquired immunity in vivo - current state of knowledge. Pol J Vet Sci 15: 583-588.

14. Radomska-Leśniewska D, Skopińska-Różewska E, Jankowska-Steifer E (2010): The effect of selected cephalosporins on angiogenic activity of human blood mononuclear cells. Centr Eur J Immunol 35: 14-19.

15. Rogala E, Skopińska-Różewska E, Bałan B, et al. (2001): The influence of cefoperazon on angiogenesis induced by homogenates of BAL cells obtained from sarcoidosis patients. Terapia 3: 18-20.

16. Skopińska-Różewska E, Nowaczyk M, Lao M, Górski AJ (1981): The effect of ampicillin on the expression of Fc-IgG receptors on human peripheral blood lymphocytes. Biomedicine 35: 41-42.

17. Skopińska-Różewska E, Kamiński M, Nowaczyk M, et al. (1985): Immunomodulatory action of ampicillin. Folia Biol (Praha) 31: 200-212.

18. Włodarska B, Bany J, Marczak M, et al. (1987): Altered immune reactivity of mice born from mothers treated with ampicillin during gestation. Folia Biol (Praha) 33: 210-215.

19. Artsimowich NG, Nastoiashchaia NN, Mul tanowskaia VN, et al. (1991): Izuchenie immunotropnoi aktiwnosti antibiotikow iz grupy aminoglikozidow. Antibiot-Khimioter 36: $27-$ 29.

20. Villa ML, Radppocido G, Piazza P, et al. (1986): The interference with antibiotics with antigen-specific antibody responses in man. Int J Immunopharmacol 8: 805-809.

21. Roszkowski W, Ko HL, Roszkowski K, et al. (1985): Antibiotics and immunomodulation: effects of cefotaxime, amikacin, mezlocillin, piperacillin, clindamycin. Med Mikrobiol Immunol 173: 279-289.

22. Forsgren A, Gnarpe H (1973): Tetracyclines and host - defense mechanism. Antimicrob Agents Chemother 6: 711-715.

23. Amurio T, Lewden S, Nicolas R, et al. (1982): Effect of treatment with clindamycin, erythromycin, rifamycin, or gentamycin on the ingestion capacity of peritoneal macrophages in mice. Pathol Biol Paris 38: 13-18.

24. Amagai T, Matsuzawa T, Cinaber B (1990): The effect of ribavirin and rifamycin $\mathrm{SV}$ on age-dependent changes of the immnune system during the adult life of SJ 1 mice. Immunol Lett 4: 149-153.

25. Demkow U, Radomska D, Chorostowska-Wynimko J, Skopińska-Różewska E (1998): Wpływ ryfampicyny na wybrane 
parametry odpowiedzi immunologicznej. Pneumonol Alergol Pol 66: 45-53.

26. Bellahsene A, Forsgen A (1980): Effect of rifampin on the immune response in mice. Infect Immun 27: 15-20.

27. Bassi L, di Bernardino L, Perna G (1979): Lack of effect of rifampin on the antibody response to a viral antigen in patients with tuberculosis. Am Rev Resp Dis 112: 739-741.

28. Radomska-Leśniewska D, Demkow U, Sokolnicka I, Chorostowska-Wynimko J: Interakcje antybiotyków i immunomodulatorów w angiogenezie immunologicznej. Terapia 2001; 3: $10-11$. 